\title{
"A Universal Narrative of Humanity«. Travelling to the >Other from Constantinople: Priscus of Panion (5th c. CE) and William of Rubruk (13th c. CE) ${ }^{1}$
}

\author{
Pia Carolla*
}

Travelling to the >Other can be fascinating - and very dangerous, especially when the traveller moves to suncivilised` peoples like Huns and Mongols. The article shows unpredictable parallels between two travel accounts very far from each other in space and time: on the one hand Priscus of Panion, a learned Greek from the 5th century CE, who goes with the Byzantine ambassador to the king of the Huns, the terrible Attila; on the other hand William of Rubruk, a learned Franciscan from the 13th century CE, who writes in Latin a detailed report about his mission to the Mongol Empire. Both cross Constantinople, the city of cities, and both bear witness to the welcoming scivilisation s they found at their destination, beyond borders and boundaries. From a literary perspective, much to our surprise, Byzantium is the key to open the world of the >Otherness`.

Keywords: Priscus of Panion, William of Rubruk, Mongol Empire, Byzantine literature, King Louis IX of France, Attila, Sartaq, Byzantium East \& West, Constantinople, >Otherness،.

Sometimes stories travel to the end of the earth, sometimes storytellers do.

In order to explore the relevance of Byzantium for the East and the West, I try to compare two narrations very far from each other in space and time: on the one hand, the text about Attila and the Huns in the 5th century CE, taken from the History of Priscus of Panion; ${ }^{2}$ on the other hand, the Itinerarium written by William of Rubruk in the 13th century, after his

* Correspondence details: Pia Carolla, Dipartimento di Italianistica, Romanistica, Antichistica, Arti e Spettacolo (DIRAAS), University of Genoa, Italy. Postal address:Antichistica - via Balbi 4, 16126 Genova, Italy. Email address: pia.carolla@unige.it

1 I am sincerely grateful to Christian Gastgeber and Ingrid Hartl for inviting and welcoming my contribution. Many thanks are to be given to Chiara Zappalà, who pointed William's Itinerarium out to me during a nice stay in Stockholm. I also wish to thank those who have shared fruitful discussion: Sergio Basso, Lucia Castaldi, Paolo Chiesa, Omar Coloru, Matilde Cupiccia, Lia Raffaella Cresci, Roberto Gamberini, Silvia Ronchey, Nicolò Sassi, Denis Searby, Giusto Traina, Kurt Villads Jensen and the Centre for Medieval Studies at the University of Stockholm, which invited to my seminar about Priscus and William in 2019.

2 For Priscus' life see Hoffmann, Priscus of Panium, a summary to be carefully checked against the sources, e.g. with the help of Given, Introduction, ix-xii. See the primary sources in the bibliography below. The excerpts and fragments in my critical edition: Priscus, Excerpta, ed. Carolla; English translation with short commentary by Given, Fragmentary History of Priscus; an older edition with excellent Italian translation by Bornmann, Prisci Panitae Fragmenta. Very important for his historical analysis and a general survey of the 5th century Blockley, Fragmentary Classicising Historians, 222-376, which has Greek text, English translation, historiographical notes and bibliography. 
return from Mongolia. ${ }^{3}$ The first was composed in Greek and is the longest extract of a work which survives through indirect manuscript tradition only; the second was written in Latin and bears witness to the literary competence of a Franciscan friar who used to live in Palestine.

They are quite different from each other, as regards the authors, the texts and the genre: the one belongs to historiography, the second is an epistle; yet they share the impact with the >Other ${ }^{4}$ Furthermore both took their leave from Constantinople: the Byzantine ambassador Maximinos convinced Priscus to take part in the embassy to Attila and their route took thirteen days from Constantinople to Serdica (today Sofia, Bulgaria). William probably sailed first from Acre (today Akko) in Palestine; then he attests to having been in Constantinople and to having spoken publicly in S. Sophia on Palm Sunday, 13th April 1253; afterwards he reached the Black Sea on 7 th May $1253^{5}$. It was the age of the Latin Empire in Constantinople (1204-1261), a different situation from Priscus' age and, in some respects, quite the opposite. ${ }^{6}$

Priscus follows in the steps of Olympiodorus and Eunapius, who were the first Greek authors to describe the Huns; most of their histories are lost, no less than Priscus' work, so that we cannot fully compare the latter's text to his models. ${ }^{7}$

The main focus from hereon is on >Otherness: my research object is the perceptions of diversity - and, indeed, of the >contrary < - by the authors and their readers. ${ }^{8}$

This entails no claim for an exhaustive analysis: it is beyond the scope of the present article to discuss theories of the >Other from Lévinas to Derrida or Foucault, the Frankfurt School, Said, De Beauvoir, Gruen and others. ${ }^{9}$ Yet the purpose of my contribution is clear: I am looking for the links between the narrations about two different peoples from the steppe, both of whom had suddenly become (in)famous and powerful and were visited by ambassadors and swindlers.

I have chosen to start from the vivid perception of the opposite by two learned authors who visited in person and who appear so keen on watching ${ }^{10}$ the `Other as to disguise their literary imitation; or, rather, to push it into the background. One can wonder why these two have been picked out from among the many reports about the Huns or the Mongols; yet, as the comparative approach needs to start somewhere and to develop gradually, it is better to ask whether this investigation has paved the way for more: hopefully, others will expand it in the future.

3 A presentation by Auzépy, Guillaume de Rubrouck; see also Vermeulen, William van Rubroec, 103. The text in Paolo Chiesa's critical edition: William, Itinerarium (with Italian translation and commentary); English translation of an older text by Jackson and Morgan, Mission of Friar William (1990); older translation by Rockhill, Journey of William of Rubruck (1900).

4 About the relationship between Byzantium and the ethnic `Other see Howard-Johnston, Byzantium and its neighbours, 939-956: 944-945; Dzino and Parry (eds.), Byzantium, its Neighbours and its Cultures.

5 Priscus, Excerpta, 8, 5, ed. Carolla, 16; William, Itinerarium I 1, ed. Chiesa, 6-8; Chiesa, Commento, 392.

6 About the Ethnic identities in Late Antiquity and Early Medieval period see Pohl, Identità etniche e cristianesimi, 59-72. For the perceptions of Byzantine identity up to the 10th century see McCormick, Eternal Victory, esp. 388396 and the bibliographical additions in the Italian version: Id., Vittoria eterna, 492 n. 7. For the Byzantine identity during the Latin empire see Kaldellis, Hellenism in Byzantium, 345-360.

7 Eunapius of Sardis, fr. 41, ed. Blockley, 58; Olympiodorus of Thebes, fr. 19, ed. Blockley, 182.

8 On the subject see Mitsiou, Byzantines and the »others«, 65-74; Laiou, Byzantium and the Other, ch. VII. The many faces of medieval colonization, 13-30, esp. 13-17; Magdalino, Constantinople and the outside world, 149-162.

9 Gruen, Rethinking the Other in Antiquity.

10 Pittaluga, Sguardo dell'altro, 23-32. 
In the following some affinities between the two texts will be shown, even though it is highly unlikely that William read Priscus. Closeness is mainly related to similar circumstances or Realien, which in turn allow us to go further and to investigate a case-study of "a universal narrative of humanity «, ${ }^{11}$ as the theme of the present cluster suggests: not only a sample of the role played by Byzantium between the East and the West, but also a comparison between the age of Attila and that of the Latin Empire in Constantinople. Needless to say, a number of differences can be detected; yet here the focus is on the similarities.

\section{The Border ${ }^{12}$}

The impact of the >Other was impressive for both authors from the very beginning, when William was still in Crimea, because the Mongol Empire looked like a different world to him: "uisum fuit michi recte quod ingrederer quoddam aliud seculum «. ${ }^{13}$

Thereafter many other borders had to be crossed, as William and his companion Bartholomeus de Cremona ${ }^{14}$ traveled from one Mongol prince to the other: from the sulus of Čaghatai to Sartaq, from Batu to Möngke to Arigh Böke, then back to Möngke again during the return trip. The first stop was at the court of Čaghatai, where they were allowed to move on to Sartaq. William was bringing to the latter a message by King Louis IX of France: Sartaq was said to have converted to Christianity and William had been asked by his king to assess in person whether the news was true. ${ }^{15}$

Taking the first step from the ulus of Caghatai to Sartaq, William had the impression to enter hell: "uisum fuit michi quod unam portam inferni transissemus «. ${ }^{16}$ Soon after that, he came across a desolate camp where people who looked like lepers collected taxes on salt. ${ }^{17}$

Priscus expressed a perception of the >Other as strong as that expressed by William, with no explicit reference to a different world or hell, by depicting desolation and misery. His first step into Attila's land brought him to a relevant destination: it was no less than Naissus, ${ }^{18}$ Constantine I's place of birth. A small town with a great ancestor; yet when Priscus got there in $449 \mathrm{AD}$, he found it devoid of living people, while the bones of the war victims were scattered everywhere and the only survivors were some seriously ill people in the hostels of

11 Vindobona. Vienna International News, Lasting Rivals - Byzantium \& the West. See also Pittaluga, Sguardo dell'altro, 23-32, who compares the accounts by William of Rubruk, John of Plano Carpini and Odoricus from Portus Naonis (Pordenone).

12 For the very notion of sfrontier in Late Antiquity, far from anachronism, see Pohl, Conclusion, 247-260: 250-254.

13 William, Itinerarium I 14, ed. Chiesa, 18; trans. Rockhill, 52 "After having left Soldaia we came on the third day across the Tartars, and when I found myself among them it seemed to me of a truth that I had been transported into another century « [actually "into a different world « (my translation)]; the same is repeated at IX 1, ed. Chiesa, 48. For the different notions of seculum and aevum see Chiesa, Commento, 344. The first border of the land controlled by Mongols was in Crimea by then, according to William three days from the town of Sudak: see also ibid., 378. The very notion of "Mongol empire « is discussed: for an overview of the political situation framing William's mission see Pubblici, Antagonism and coexistence, esp. 25-27.

14 William, Itinerarium I 10, ed. Chiesa, 14; see also Chiesa, Commento, 340.

15 William, Itinerarium I 6-7, ed. Chiesa, 12. About Sartaq see Chiesa, Commento, 335.

16 William, Itinerarium XII 3, ed. Chiesa, 58.

17 William, Itinerarium XII 4, ed. Chiesa, 60.

18 Today Niš, Serbia. 
the church ${ }^{19}$. To represent that 'waste land,, so to speak, Priscus turned to Homer, mixing the literal imitation of Iliad 8 with an allusion to the Sirens' island in Odyssey $12 .{ }^{20}$ So he vividly depicted the "boundary between Scythian and Roman territories" as a border hostile to manhood. ${ }^{21}$

A first similarity is thus to be detected between the two accounts: entering the >Otherness means passing from a safe zone to uncertainty, where the border is a sort of ghost place, a no-man's-land.

\section{Wandering in the Steppe}

The path towards Attila's camp in Pannonia was tortuous and unpredictable, as is well documented by Priscus in his excerpt 8, 16: „We came into a thickly shaded area with many bends, twists and turnabouts. When day appeared, we believed we were journeying toward the west, but the rising sun appeared before us. Those inexperienced with the lay of the land cried out, believing that the sun was traveling backward and signifying more unexpected events. But thanks to the topographical irregularity that part of the road was looking east. « $^{22}$ Priscus was said to be a master in rhetoric: that is why we can label this passage an aprosdoketon, which was widely used in late antique literature and beyond. ${ }^{23} \mathrm{~A}$ modern reader appreciates the downplaying of the mostrum (i.e., the wonder) in the name of reason, although superstitious beliefs about the sun turning eastbound can be found up to our present; ${ }^{24}$ yet in the 5 th century it was probably perceived as just one of a million variations on the theme of the famous prolonged night of Odysseus and Penelope in Odyssey 23. Most of those variationes were scholastic products (Progymnasmata) and came easily to the mind of a master in rhetoric, without necessarily being an allusion any more. ${ }^{25}$ However, the fact that Priscus could immediately skip both any millenarianism and fear of "more unexpected events" means that he was not scared by entering the >Othernessı. Or at least he wanted to create that impression.

19 Priscus, Excerpta, 8, 13-14, ed. Carolla, 18; trans. Given, 49: "Arriving at Naissos, we found the city bereft of people because it had been overturned by the enemy, though there were some people in the sacred lodgings who were suffering from diseases. We camped a little bit upriver in a clearing, since the bank was everywhere covered with

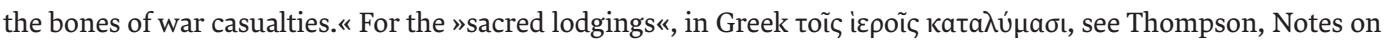
Priscus, 63: »the Christian hostels«.

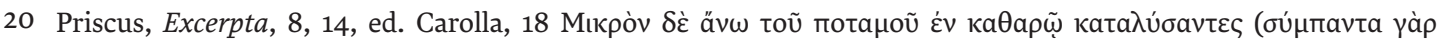

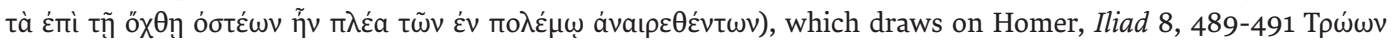

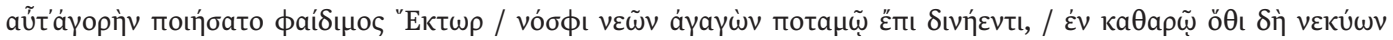

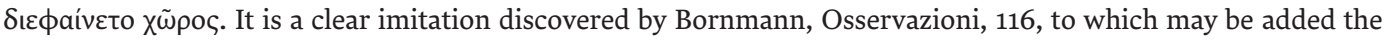
evocation of the bones around the Sirens in Circe's prophecy to Odysseus: Homer, Odyssey 12, 44-46 á $\lambda \lambda$ á $\tau \varepsilon$

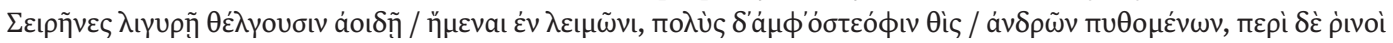

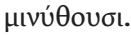

21 Attila had ordered that Naissus be the new marketplace in Illyria, instead of the older one on the Danube: Priscus, Excerpta, 7, 3, ed. Carolla, 13; trans. Given, 45. So the king of the Huns commanded the Byzantine Empire to withdraw »a five days' journey« (ibid.).

22 Priscus, Excerpta, 8, 16, trans. Given, 49; see the Greek text with apparatus fontium, ed. Carolla, 18-19.

23 For Suidas and Evagrius as testimonia to Priscus' ability in rhetorics see Testimonia de Prisco, in: Priscus, Excerpta, ed. Carolla, XLVIII.

24 The paradox e.g. in Manfredi, Faraone delle sabbie, 333.

25 About Progymnasmata see recently Berardi, Retorica degli esercizi preparatori, with bibliography. 
William had a quite similar experience, but with horses rather than with the sun: while wandering in the steppe they met no human being for days in a row and at the end they felt exhausted and lost; then, all of a sudden, two horses came towards them and they cried out in joy and relief. ${ }^{26}$ This time everybody was overwhelmed and there was neither downplaying nor overstating: William presents his own feeling as perfectly natural after the desolation of the steppe. Elsewhere he says that God chose the Mongol people as an instrument for His will, ${ }^{27}$ so he is familiar with Christian interpretation of history, but here he just sticks to the facts and gives us a round representation of a psychological phenomenon: the simple presence of animals as friends helped the men beyond expectation. One can infer that the author could recognise and express his feelings without exaggerating them.

\section{Nomadic Life}

Whenever in contact with the peoples they are visiting, nomadic life is the first feature for both Priscus and William.

Contrary to the collective image of the Huns, they had been settled in Pannonia for a long time when Priscus met them, yet Attila's camp was still traveling, in this way controlling land and tribes.$^{28}$ And everything could be discussed and settled on horseback, including food and drink receptions: for example, while still astride his horse, Attila received offerings from the wife of his collaborator Onegesios. ${ }^{29}$

The same can be noted about the Mongols according to William, who was impressed by the camp and wagons as well: "Nusquam habent manentem ciuitatem, sed futuram ignorant $"{ }^{30}$ Some pages can be fascinating for readers, especially when he reports having paced along some carts, to measure their width: »Ego enim mensuraui semel latitudinem inter

26 William, Itinerarium, XIII 14, ed. Chiesa, 68.

27 William, Itinerarium, XXI 4, ed. Chiesa, 104.

28 Huns were no more the wild barbarians described by Ammianus Marcellinus, Res gestae, XXXI 3-4 »In hominum autem figura licet insuavi ita visi sunt asperi, ut neque igni neque saporatis indigeant cibis sed radicibus herbarum agrestium et semicruda cuiusvis pecoris carne vescantur, quam inter femora sua equorumque terga subsertam fotu calefaciunt brevi. Aedificiis nullis umquam tecti sed haec velut ab usu communi discreta sepulcra declinant. Nec enim apud eos vel arundine fastigatum reperiri tugurium potest. Sed vagi montes peragrantes et silvas, pruinas famem sitimque perferre ab incunabulis adsuescunt. Peregre tecta nisi adigente maxima necessitate non subeunt: nec enim apud eos securos existimant esse sub tectis. "Yet Attila was still traveling with a tent, see e.g. Priscus, Excerpta, 8, 22, ed. Carolla, 20; §38, ibid., 23; §§41-48, ibid., 23-25; §83, ibid., 32; exc. 8.1, 1, ibid., 51; etc. Kelly, Neither conquest nor settlement, 195: "Certainly by the 420s, the Huns were firmly established on the Great Hungarian Plain in the heart of Europe, the only area of grassland west of the Black Sea capable of supporting horses on any scale and an ideal base for military operations on both sides of the Rhine and Danube."See also Maas, Reversals of fortune, 7-9 and 17-20; Thompson and Heather, Huns, esp. 41-62; Pohl, Migrations, ethnic groups, $247-263$.

29 Priscus, Excerpta, 8, 88, ed. Carolla, 32-33; trans. Given, 61 »As Attila approached Onegesios's compound (for the road to the palace ran through it), Onegesios's wife came out with a multitude of servants, some of whom were carrying food and others wine. This is a very great honor among Scythian women. She greeted him and begged him to partake of what she was kind-heartedly offering him. Showing favor to the wife of his adviser, he ate sitting on his horse as the barbarians accompanying him raised the platter up to him. It was made of silver."

30 William, Itinerarium, II 1, ed. Chiesa, 18; trans. Jackson and Morgan [e-book]: "Nowhere have they any >lasting city<; and of the sone to comer they have no knowledge«. See Chiesa, Commento, 344: the sentence is taken verbatim from Hebrews 13, 14 "non habemus hic manentem ciuitatem, sed futuram inquirimus «. About the purpose of riding together, see William, Itinerarium, XX 5, ed. Chiesa, 100; trans. Rockhill, 128: »I saw Baatu riding with all his horde; and all the heads of families were riding with him, but according to my estimate there were not over five hundred men.« 
uestigia rotarum unius bige $\mathrm{XX}$ pedum, et quando domus erat super bigam excedebat extra rotas in utroque latere $\mathrm{V}$ pedibus ad minus. Ego numeraui in una biga XXII boues trahentes unam domum, undecim in uno ordine secundum latitudinem bige, et alios XI ante illos; axis bige erat magnus ad modum arboris nauis, et unus homo stabat in hostio domus super bigam minans boues. $\aleph^{31}$

From a literary perspective, writing about the Mongol nomadic life could also be either a way to pay homage to John of Plano Carpini, the Franciscan friar who had visited the khan's court some years before William; ${ }^{32}$ or, even better, a way for William to distance himself from John.

\section{Ambassadors \& Conspiracies}

The work of John was the closest literary model for William, although some dislike can be perceived between the lines of the latter. ${ }^{33}$ William planned his Itinerarium with a structure similar to that of John, yet he insisted on the main difference, namely, that he was no ambassador whatsoever: he was only a preacher looking for conversions of both the powerful and the common Mongol people. ${ }^{34}$ Far from being a stereotype, William's claim could be dangerous: at the very beginning of his travels, the Byzantine traders in Crimea had advised him to accept being believed an ambassador, otherwise he could be rejected; ${ }^{35}$ soon after, he also learnt that Mongols used to execute people pretending to be ambassadors, ${ }^{36}$ probably charging them with being secret agents.

31 William, Itinerarium, II 2, ed. Chiesa, 18-20; trans. Jackson and Morgan [e-book]: "I myself once measured a breadth of twenty feet between the wheeltracks of a wagon, and when the dwelling was on the wagon it protruded beyond the wheels by at least five feet on either side. I have counted twenty-two oxen to one wagon, hauling along a dwelling, eleven in a row, corresponding to the width of the wagon, and another eleven in front of them. The wagon's axle was as large as a ship's mast, and one man stood at the entrance to the dwelling on top of the wagon, driving the oxen".

32 John of Plano Carpini was sent as a papal legate by Pope Innocent IV, Sinibaldo Fieschi, with a letter to the Mongol Great Khan at Qara-Qorum. His travel lasted from 1245 to 1247 and visited Güyük Khan, bringing back an official answer to the pope.

33 Paolo Chiesa, pers. comm., 16 March 2019.

34 Most of the Itinerarium is reworked by William on his notes taken during the journey, precisely like Priscus; once back in Palestine, William added a long general overview about the Mongols' habits and traditions, following a structure similar to John's: William, Itinerarium, II 1-VIII 5, ed. Chiesa, 18-46; John of Plano Carpini, Historia Mongalorum, 1, ed. Menestò, 229 »Volentes igitur facta scribere Tartarorum, ut lectores valeant facilius inuenire, hoc modo per capitula describemus. Primo dicemus de terra, secundo de hominibus, tertio de ritu, quarto de moribus, quinto de ipsorum imperio, sexto de bellis, septimo de terris quas eorum dominio subiugarunt, octavo quomodo bello occurratur eisdem (...)« For the persistent claim to be no ambassador see e.g., William, Itinerarium, I 6, ed. Chiesa, 12; XXXVI 13, ibid., 278-280. He was well aware of the difference between them on this point, see XIX 5, ed. Chiesa, 94 » fuerat enim ibi frater Iohannes de Policarpo [sic], sed ipse mutauerat habitum ne contempneretur, quia erat nuncius domini pape«. See also Chiesa, Introduzione, XXXV-XXXVI.

35 William, Itinerarium, I 6-7, ed. Chiesa, 12.

36 William, Itinerarium, VIII 2, ed. Chiesa, 44 "Item falsos nuncios, qui scilicet faciunt se nuncios et non sunt, interficiunt«; XIX 13, ibid., 170 »Tales trufatores currunt per mundum, quos Moal [i.e., Mongols] interficiunt, cum possunt eos deprehendere.« 
Priscus' journey to Attila became no less dangerous because there was, genuinely, an ongoing Byzantine conspiracy to kill Attila without the ambassador's knowledge. Priscus was no ambassador either: he went with Maximinus, who was in charge of the embassy and implored him to go together. ${ }^{37}$ The conspiracy was based on bribery of the Hun ambassador, named Edekon, who had come to Constantinople and then travelled back with Maximinus and Priscus. Edekon should have killed Attila, with the collaboration of other Hun noblemen. Eventually, Edekon informed Attila of the conspiracy instead, and the king decided to take advantage from the situation, sending back the Byzantine spy and letting him collect the gold intended to pay the killers, only to seize it all on his return and to ask for more as a ransom. This is why he spared Maximinus and Priscus' lives. The spy was their interpreter, Vigilas the Goth, who worked directly for the Byzantine magister officiorum Martialios and was allegedly engaged in the conspiracy by the powerful spatharius Chrysaphius. ${ }^{38}$

While in Qara-qorum, William was asked about everything he had to do there, because Möngke the Khan had had news of a conspiracy: no less than four hundreds "Hacsasini“ were said to have been diguised »in diuersis habitibus « to kill him ${ }^{39}$. That was why he ordered that every ambassador be questioned thoroughly.

It is no wonder: ambassadors and embassies were exposed to infiltrators, and interpreters were the most suitable profile for spies, such as in the case of Priscus.

\section{The Role of the Interpreter}

William had an interpreter travelling with him from the beginning, whose name was "Homo Dei«. William considered him really disappointing because the man could not translate properly what he mostly wanted, namely, his preaching Christianity to the Mongols. Some scholars have suggested that he was a native Arab from Palestine and that he was called 'Abd-Allāh. ${ }^{40}$. While this point is impossible to ascertain, the man's ineptitude in translating

37 No specific/official role of Priscus is mentioned; see Baldwin, Priskos; Given, Introduction, xii: »It is possible that Priscus held an official position on this and subsequent embassies, and that he was appointed to the missions because of some office he held in the Constantinopolitan bureaucracy. The language, though, suggests that Priscus did not receive an official appointment. It seems more likely that he followed Maximinos as an unofficial adviser and, given his training (see below), as an assistant in the skills of political and diplomatic rhetoric«. See also ibid., xli n. 1: »It used to be scholarly opinion that Priscus worked as a scriniarius, a minor bureaucrat in a financial or legal office. This belief turned on the identification of the ambassador Maximinos with a man of the same name who worked on the Theodosian Code as a magister scrinii. As this identification has been called into question, so too has Priscus lost his official employment. See, though, Treadgold [Early Byzantine Historians], 97, who revives the possibility«.

38 For Edekon see PLRE 2, 385-386. The conspiracy was planned by Chrysaphius, the eunuch spatharius of the emperor Theodosius II, who shared with his master his pure hatred of Priscus. See e.g. Priscus, Excerpta, 7, 5-4, ed. Carolla, 13-15; exc. 12, 1-4; exc. 12.1, 1; exc. 13, 1-4, ibid., 53-55, and elsewhere. On the powerful eunuch, see Chrysaphius qui et Ztummas, PLRE 3, 295-297.

39 William, Itinerarium, XXXII 2, ed. Chiesa, 232. For the »Hacsasini«, from the Arab »Hashāshīn (etymology of the Western word »assassin«), see Chiesa, Commento, 400.

40 William, Itinerarium, I 10, ed. Chiesa, 14. See Chiesa, Commento, 340-341. For the ineptitude, see XIII 6, ed. hiesa, 64 "Super omnia autem grauabat me quod quando uolebam eis dicere aliquod verbum edificationis, interpres meus dicebat: `Non faciatis me predicare, quia nescio talia uerba dicere!^ Et uerum dicebat. Ego enim percepi postea, quando incepi aliquantulum intelligere ideoma, quod quando dicebam unum, ipse totum aliud dicebat, secundum quod ei occurrebat.« 
concepts may be connected to a lack of familiarity with Christianity itself. Furthermore, to have one single interpreter is something that William regrets throughout. One might recall St. Francis, the founder of the Franciscans, who must have found very good interpreters for his preaching to Sultan al-Malik al-Kāmil at Damietta in $1219 .{ }^{41}$ The founder of the order was a model of preaching for William: after all, the latter belonged to the order of the Friars Minor and was sent on a very risky mission like many friars elsewhere. ${ }^{42}$

Priscus did not regret the interpreter's ability overtly, but pictured Attila's rage against him: it was the king of the Huns who yelled at Vigilas and attacked him with harsh words as soon as he entered the tent. ${ }^{43}$ The reader can $>$ decoder the situation, because he is well informed of the crucial role of the interpreter into the conspiracy; the persona auctoris, on the contrary, was completely in the dark at that moment.

Interpreters also suggested both to Priscus and to William that they should appease the >Other`, whatever he asked. The first issue was a strange request by the Hun leaders: a number of them came, riding on horseback, and surrounded the Byzantine entourage, who stood in the middle. The Hun $\lambda$ oүá $\delta \varepsilon \varsigma,{ }^{44}$ i.e., snoblemen«, staying on horseback, asked to be informed in advance of what Maximinus was going to say to Attila. The ambassador resisted the impossible demand and invoked the usual practice of diplomatic mission between Byzantium and the Huns from old times: no one but Attila was intended to know the emperor's letter and the oral message he had come to deliver. The Huns immediately left them and suddenly returned, listing every point of the Byzantine embassy. How could they know? Then Maximinus was ordered to tell them whether there was something else left to say; after his refusal to comply, he was obliged to go back to Constantinople straight away. At this point Vigilas the interpreter reproached him for his behaviour: a lie, in his opinion, would have been better than nothing. ${ }^{45}$ Again, the reader can read between the lines: Vigilas' suggestion came from greediness and could be fully explained by the ongoing conspiracy. In other words, Priscus' highlighting the episode was a literary way of 'ंӨoпой̈а or characterisation, ${ }^{46}$ and the message perceived by the reader was that the interpreter made the situation worse. In our modern perspective and terminology: the interpreter should have been a facilitator, whereas he enlarged the distance between the ambassador and the ১Other».

41 Ernoul, Chronicle, ed. Golubovich, 10-13 (datable between 1227 and 1229); see later (1263) Bonaventura, Legenda Maior, IX 7-8. For the Sultan see Gottschalk, »al-Kāmil«. The episode has been reconsidered by many scholars: see Ibrahim, Francis preaching to the sultan, (about the retelling of the meeting "in visual and textual sources between 1228 « and 1500, with bibliography).

42 About the literature of the new orders such as Franciscans and Dominicans see e.g. Chiesa, Introduzione, XLVI; see also Pittaluga, Sguardo dell'altro, 23-32.

43 Priscus, Excerpta, 8, 43-44, ed. Carolla, 24; trans. Given, 53-54 »He turned his attention straight to Bigilas, called him a shameless beast and asked why he wanted to come to him [...]. Growing angrier and reviling him all the more, Attila shouted that he would have crucified him and given him as food to the birds, if he did not think inflicting this penalty on his shamelessness and on the effrontery of his words would violate sacred diplomatic law." Note that Attila shows himself as caring a great deal about the dignity of ambassadors.

44 Priscus, Excerpta, 8, 23, ed. Carolla, 20 and elsewhere.

45 Priscus, Excerpta, 8, 23-30, ed. Carolla, 20-21; see also 35, ibid., 22.

46 It is explicitly added by Priscus himself, even though there is some verb missing here in the manuscripts: Priscus, Excerpta, 8, 31-32, ed. Carolla, 21; trans. Given, 51: "He said this, <believing> Edekon [i.e., the accomplice of the conspiracy] remained friendly toward him, so that, under the pretext of the embassy and of saying anything, true or false, he might find an excuse to discuss their intentions against Attila and how to convey the gold Edekon said he needed to pay the men appointed to perform the task. But Edekon had secretly betrayed him.« 
William underwent a similar treatment while arriving at the camp of Čaghatai: they were surrounded by men riding on horseback, ${ }^{47}$ who asked of them what the purpose of their mission was. William refused to tell anyone but Sartaq and proclaimed that it was none of their business, otherwise he would have gone back immediately. ${ }^{48}$ In this case William did not complain about the interpreter, which makes us think that Homo Dei was able to translate practicalities.

However, William complained when the interpreter was willing to donate everything they had at the court of Sartaq. It is easy for the reader to understand that the man was acting out of fear, anxious to be allowed to eat and to continue their journey; yet William depicts him as a coward and a bungler: »Timebam etiam de interprete, ne ipse aliquid aliter dixisset quam ego dixissem ei, quia ipse bene uoluisset quod de omnibus fecissemus exennium. « ${ }^{49}$

Elsewhere, William himself was willing to reveal in advance the contents of his mission. This was the case at Möngke's court, where he complied without hesitation before entering the khan's hearing. ${ }^{50}$ A contradictory behaviour was here felt obvious by both the author and the reader, once they had become familiar with the many difficulties of the mission to the >Other<.

\section{Dwellings \& Capitals}

Not only the interpreter was impressed, and not only by the Mongol power: their camps were impressive, as we have seen, as well as their capitals. When William entered the camp of Batu, he had a scary sensation of seeing a huge city, even though those were just Batu's dwellings: "Quando ergo uidi curiam Baatu expaui, quia uidebantur proprie domus eius quasi quedam magna ciuitas protensa in longum, et populus undique circumfusus usque ad tres uel quatuor leucas. « ${ }^{51}$

Priscus and his company often camped, during their travels, also before meeting the king and his entourage. ${ }^{2}$ As soon as they entered Attila's camp, he was impressed by the number of tents. Furthermore, he noted that location was used as a means of preserving a distinction: Attila's tent had to be higher than the others, both while traveling and when they stopped. ${ }^{53}$

William will also mention several times the strict hierarchical system as regards the location of tents or carriages. ${ }^{54}$

The same happens later, when they are at Sartaq's camp: see William, Itinerarium, XV 5, ed. Chiesa, 74.

48 William, Itinerarium, IX 1, ed. Chiesa, 48.

49 William, Itinerarium, XVI 3, ed. Chiesa, 78-80; trans. Jackson and Morgan, [e-book]: "I was also afraid that the interpreter had said something different from what I had told him, as he would have quite liked us to make a gift of everything«.

50 William, Itinerarium, XXVIII 2, ed. Chiesa, 144.

51 William, Itinerarium XIX 4, ed. Chiesa, 92; trans. Rockhill, 122: »When I saw the ordu of Baatu, I was astonished, for it seemed like a great city stretched out about his dwelling, with people scattered all about for three or four leagues."

52 Priscus, Excerpta, 8, 14, ed. Carolla, 18 at Naissus, because the town had been destroyed by the Huns (see above).

53 Priscus, Excerpta, 8, 22, ed. Carolla, 20; trans. Given, 50: »Around the ninth hour of the day we reached Attila's tents (and there were many tents there). We wanted to pitch ours on the crest of a hill, but the barbarians who met us prevented it, since Attila's tent was on lower ground«. See also 8, 41, ed. Carolla, 24; trans. Given, 53 »And so at last we came to Attila's tent, which was guarded by a barbarian multitude arrayed in a circle."

54 William, Itinerarium II 4, ed. Chiesa, 22; XIX 4, ibid., 92; XXIX 30-31, ibid., 184, et passim. 
Afterwards, when Priscus reached the unnamed scapitalı of Attila's kingdom, he saw separate houses for Attila and for Kreka, his most important wife. Whereas Attila had real houses, made of stone and wood, all the more precious because of the absence of both kinds of material in the steppe, Kreka, in fact, had some wooden houses and others made of something (»words") which was corrupted in the manuscript tradition. They were nothing else but yurts, as I have discovered during the emendatio of Priscus' text. ${ }^{55}$

Yurts are described with accuracy by William in his excursus about the habits and traditions of the Mongols. It is an ekphrasis - a learned technical description, intended for the addressee of the Itinerarium: the King Louis IX of France, who could fully appreciate it. ${ }^{56}$ "Domum in qua dormiunt fundant super rotam de uirgis cancellatis, cuius tingna sunt de uirgis et conueniunt in unam paruulam rotam superius, de qua ascendit collum sursum tamquam fumigatorium. Quam cooperiunt filtro albo, et frequentius imbuunt etiam filtrum calce uel terra alba et puluere ossium ut albius splendeat, et aliquando nigro; et filtrum illud circa collum superius decorant pulchra uarietate picture. Ante hostium similiter suspendunt filtrum opere polimitario uariatum: consuunt enim filtrum coloratum in aliud, faciendo uites et arbores, aues et bestias. Et faciunt tales domos ita magnas, quod habent aliquando triginta pedes in latitudine. ${ }^{57}$

55 Priscus, Excerpta, 8, 129, ed. Carolla, 39. See the critical apparatus, line 10: all the manuscripts have tà $\delta \dot{\varepsilon}$

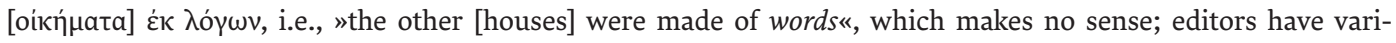
ously tried to correct it, until Bornmann, Prisci Panitae Fragmenta, 52 decided to put a crux desperationis here, i.e., showed that the passage is definitely corrupted. Thanks to the complete collation of all the manuscripts (including Cambridge, Trinity College, O.3.23 which was ignored by Carl de Boor in 1903) I was able to amend the

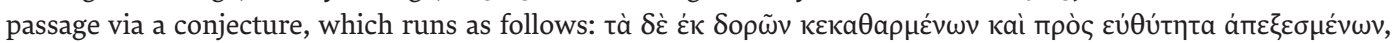

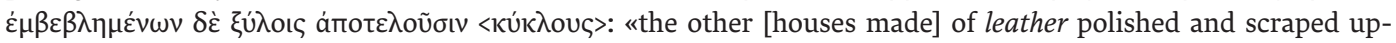
right, put into some wooden circular basis» (my translation). A different interpretation of the passage in trans. Given, 67 (text) and 90 n. 42 (commentary), who here follows Thompson, Camp of Attila, 113-114 and Priscus, Fragmenta 11.2, ed. Blockley, 274, as regards textual criticism.

56 The Itinerarium takes the form of an epistle, in order to be adequate for the rank of the king; see Chiesa, Introduzione, XLVI-XLVII.

57 William, Itinerarium II 2, ed. Chiesa, 18; trans. Jackson and Morgan [e-book]: »The dwelling in which they sleep is based on a hoop of interlaced branches, and its supports are made of branches, converging at the top around a smaller hoop, from which projects a neck like a chimney. They cover it with white felt: quite often they also smear the felt with chalk or white clay and ground bones to make it gleam whiter, or sometimes they blacken it. And they decorate the felt around the neck at the top with various fine designs. Similarly they hang up in front of the entrance felt patchwork in various patterns: they sew onto one piece others of different colours to make vines, trees, birds and animals. These dwellings are constructed of such a size as to be on occasions thirty feet across". See Chiesa, Commento, 345-346: Mongolian traditional houses are very similar to those from the 13th century. This passage, as well as the whole excursus about Mongolian uses \& traditions, was probably composed by William later than the rest (see above): Chiesa, Introduzione, XLIX-L. For literary parallels, see e.g. John of Plano Carpini, Historia Mongalorum, 2 (my italics) "Stationes rotundas habent in modum tentorii praeparatas, de virgis et baculis subtiliter factas. Supra vero in medio rotundam habent fenestram vnde lumen ingreditur, et vt possit fumus exire: quia semper in medio ignem faciunt. Parietes autem et tecta filtro sunt cooperta. Ostia etiam de filtro sunt facta. Quadam stationes sunt magna, quadam parua, secundum dignitatem et hominum paruitatem«. Note that William uses as much variatio as he can, comparing and contrasting John of Plano Carpini. 
What is relevant is the similar perspective, provided by Priscus and William: they stressed the circular base, the remarkable height of the circle and the huge size of some yurts. ${ }^{58}$ Most of all, they were really interested in the beautiful handicrafts which adorned the yurts, both inside and out. Priscus highlighted the fact that he found Attila's wife "lying on a soft mattress. The ground was covered with woollen felt pieces for walking on." Then he insisted: »female servants sat on the ground opposite her, dyeing some fine linens that were to be placed over the barbarians' clothing as adornment. ${ }^{59}$ The reader can feel the amazement of the author, who probably did not expect that much from his stay at Attila's.

As for William, we have seen his insistence on the coloured decoration on top of the yurts, as well as on the beautiful patchwork felt door. Furthermore, the patterns of "vines and trees, birds and beasts « spoke of a care for beauty by the Mongols, and the detail points to a positive view by the author as well. John of Plano Carpini had described the same things with a focus on technical details, rather than on those beautiful designs. ${ }^{60}$

\section{Beauty and ugliness}

Beauty surprised Priscus on several occasions during his stay at Attila's court. The same "capital" (with no name in his report) where he visited Kreka, the king's most important wife, was "a very large village, in which it was said Attila's compound was more conspicuous than everyone else's, fitted together with logs and well-polished boards and encircled with a wooden wall that contributed not to safety but to majesty « [my italics]. ${ }^{61}$ And the Getica of Jordanes, who drew on Priscus via Cassiodorus' Historia Gothorum, echoed: "A little ways on, we approached the village in which king Attila was tarrying, a village, I say, resembling a very populous city. We found there wooden walls made of shining planks, the interconnection of which mimicked something so solid that the planks' seam could hardly be seen even by someone looking for it. You could see dining rooms of great circumference and porticoes adorned with every beautification. The court's open space was embraced by so large a circuit that its very size displayed royal dignity. This was the dwelling of king Attila, who held the entire barbarian world. He preferred this abode to the cities he had captured. « ${ }^{62}$

58 See above, fn. 55: «the other [houses made] of leather polished and scraped upright, put into some wooden circular basis», and the following: Priscus, Excerpta, 8, 129, ed. Carolla, 39; trans. Given, 67 »The circles, starting from the ground, rose up to a height of good proportion«. About the size of the yurt see ibid., 131, ed. Carolla, 39; trans. Given "A number of male servants were gathered round her while female servants sat on the ground opposite her, dyeing some fine linens that were to be placed over the barbarians' clothing as adornment." The presence of a `crowd $\varsigma(\pi \lambda \tilde{\eta} \theta$ oc) of servants depicts a royal situation, with appropriate proportion between space and people. William insists on the circular basis (»super rotam de uirgis cancellatis») and the smaller swheek above it (»in unam paruulam rotam superius «); the size is given immediately afterwards: »tales domos ita magnas, quod habent aliquando triginta pedes in latitudine«.

59 Priscus, Excerpta, 8, 130-131, ed. Carolla, 39; trans. Given, 67.

60 See above, fn. 50. For William's positive view, see Pittaluga, Sguardo dell'altro, 23-32.

61 Priscus, Excerpta, 8, 83, ed. Carolla, 32: trans. Given, 59.

62 Jordanes, Getica, 178-179, ed. Giunta and Grillone, 104-105 = Priscus, Excerpta, 9, ed. Carolla, 52: "[...] ad vicum in quo rex Attila morabatur, accessimus, vicum, inquam, ad instar civitatis amplissimae, in quo lignea moenia ex tabulis nitentibus fabricata repperimus, quarum compago ita solidum mentiebatur, ut vix ab intento posset iunctura tabularum comprehendi. Videres triclinia ambitu prolixiore distenta porticusque in omni decore dispositas; area vero cortis ingenti ambitu cingebatur, ut amplitudo ipsa regiam aulam ostenderet. Hae sedes erant Attilae regis, barbariem totam tenentis, haec captis civitatibus habitacula praeponebat.« Trans. Given, 60. 
While Priscus is amazed by beautiful buildings, flatware, textiles, decorations and people, ${ }^{63}$ William is struck by the ugly pug-nosed women and their black makeup. ${ }^{64}$ Yet the Mongols display beautiful things and buildings as well, so he reports accurately every surprising detail, especially the great palace and its brick wall at Qara-Qorum, when William got there together with Möngke. "Ipse Mangu habet apud Caracarum magnam curiam iuxta muros uille, clausam muro latericio, sicut clauduntur prioratus monachorum apud nos. Ibi est unum magnum palatium in quo tenet potationem suam bis in anno [...]. Sunt ibi multe domus longe sicut grangie, in quibus reconduntur cibaria sua et thesauri sui. ${ }^{65}$ From a literary perspective, the palace is just preparation for an ekphrasis about a handicraft masterpiece, moreover a French one. Another Guilelmus, a French goldsmith who came from Paris and lived in Qara-Qorum at Möngke's service, had prepared his best work at the Mongol court precisely when William was there: a silver fountain in the form of a tree, spreading in four branches wine, beer, milk and sbalk. The description takes up several pages in the Itinerarium, and the artisan was a key person in William's journey. ${ }^{66}$

So both courts, the Hun and the Mongol ones, become places of beauty in the imagination of the readers.

\section{Freedom, Slavery and Polities}

No stone was to be found in the steppe to build houses, neither for the Huns in Pannonia ${ }^{67}$ nor for the Mongols in their vast empire: William reports tombs made of stones by the people of Comans, "although there was no stone«; they were the only building during his journey to Sartaq, like a spectral presence in a desert. ${ }^{68}$ Just like Priscus, he highlights the fact that building materials are worth a lot.

63 Priscus, Excerpta. 8, 88, ed. Carolla, 33; 161-162, ibid., 45 (flatware); 8, 87, ibid., 32; 154, ibid., 44 (textiles); see also above about Kreka's felt carpets; 8, 72, ibid., 29 (women); trans. Given, respectively, 61; 73; 61; 72; 57. About stone buildings, see below the following paragraph.

64 William, Itinerarium $\mathrm{X}$ 3, ed. Chiesa, 52.

65 William, Itinerarium XXX 1, ed. Chiesa, 210; trans. Rockhill, 207 »Mangu had at Caracarum a great palace, situated next to the city walls, enclosed within a high wall like those which enclose monks' priories among us. Here is a great palace, where he has his drinkings twice a year [...]. There are there many buildings as long as barns, in which are stored his provisions and his treasures."

66 William, Itinerarium XXX 1-4, ed. Chiesa, 210-214. For William's consideration about Guilelmus the goldsmith see esp. XXXVI 19, ibid., 284.

67 Priscus, Excerpta, 8, 85, ed. Carolla, 32; trans. Given, $60 »$ The barbarians of that region do not have a stone nor even a tree, but they use imported wood in this way."

68 William, Itinerarium, VIII 4, ed. Chiesa, 47: »alicubi lapideas domos, quamuis lapides non inueniantur ibi«; for the spectral landscape, see ibid. XII 5, ed. Chiesa, 60 »Et tendebamus recte in orientem (...) habentes mare ad meridiem et uastam solitudinem ad aquilonem, que durat per $\mathrm{xx}$ dietas alicubi in latitudine, in qua nulla silua, nullus mons, nullus lapis, herba optima.« See also Chiesa, Introduzione, XLIX. 
The author from Panion is especially interested in the story of the Illyrian architect, a prisoner of war who became a slave of Onegesios, sthe preeminent man among the Scythians after Attila". Onegesios requested of him that he build a bath »by conveying stones from Paionia « and the architect hoped to be rewarded with freedom, but he became the bath attendant for Onegesios and his fellowship instead. So "he unexpectedly fell into worse hardship than slavery among the Scythians. « ${ }^{69}$

Priscus recounts meeting another former prisoner of war, a Greek from Sirmium, who had had a brilliant recovery from slavery. The man greeted Priscus in Greek ("Xaĩp\&«), looked wealthy and felt satisfaction at his own life. It is the most renowned passage of Priscus' excerpts, where the vibrant dialogue between the two about the politeia of the Romans is reported. The Greek, naturalised by the Huns, had chosen to defend Attila's world because of his own better life, so he strongly criticised the Roman Empire for military ineptitude, official misconduct by the governors and bribery; Priscus, on the other hand, encountered problems in answering but insisted on the fact that good fortune among Huns was just by chance, while the Roman politeia was the best constitution ever. At the end, the man turned to tears and »he said that the laws were noble and the Roman constitution good, but the rulers, since they do not think like rulers of old, had corrupted it. « $^{70}$

The passage has been discussed and doubted. Was it mere criticism towards the emperor Theodosius II, rhetorically disguised as happens in Greek and Byzantine historiography? Did the dialogue really take place or was it invented by the author? ${ }^{71}$

The comparison with William's Itinerarium hints at the veracity of the meeting: even the Franciscan friar met a person from the Coman people who was delighted to greet him and his companion in Latin: "Saluete, domini! $\aleph^{72}$ Also the reaction was quite similar to Priscus: the Greek historian had "returned his greeting and asked who he was and from where he had come to the barbarian land and taken up the Scythian life." The other wondered at his wondering, so Priscus pointed out that "his speaking Greek was the cause" of his »inquisitiveness «. ${ }^{73}$ On his part, William was astonished by the Coman: »Ego mirans, ipso resalutato, quesiui quis eum docuerat illam salutationem." The Coman explained that he »in Hungaria fuit baptizatus a fratribus nostris qui docuerant eam « ${ }^{74}$ No news of a political talk here, of course: the focus is on the Franciscans - on the one hand, William and Bartholomeus; on

69 Priscus, Excerpta, 8, 84-86, ed. Carolla, 32; trans. Given, 60-61: [the compound of Onegesios] "was not equipped with towers like Attila's; rather there was a bath, not far from the enclosing wall, which Onegesios, as the preeminent man among the Scythians after Attila, built large by conveying stones from Paionia. The barbarians of that region do not have a stone nor even a tree, but they use imported wood in this way."

70 Priscus, Excerpta, 8, 94-114, ed. Carolla, 34-37; trans. Given, 62-65.

71 The episode is taken at face value by Greatrex, Government and mechanism, 37-38; Lenski, Captivity among barbarians, 230-246, esp. 240-241; see also Thompson, Notes on Priscus, 63-64; Thompson and Heather, Huns, 161-166; Priscus, Fragmenta, ed. Blockley, 385-386 n. 59.

72 William, Itinerarium XX 4, ed. Chiesa, 100; trans. Rockhill, 127: "One day a Coman joined us, who saluted us in Latin, saying: sSalvete domine! Much astonished, I returned his salutation, and asked him who had taught it him. He said that he had been baptized in Hungary by the brethren of our order, who had taught it to him«. See Chiesa, Introduzione, LIV.

73 Priscus, Excerpta, 8, 96-97, ed. Carolla, 34; trans. Given, 62.

74 William, Itinerarium XX 4, ed. Chiesa, 100; trans. Rockhill, 127: »Much astonished, I returned his salutation, and asked him who had taught it him. He said that he had been baptized in Hungary by the brethren of our order, who had taught it him.« 
the other, the anonymous friars in Hungary where the man was baptised. Yet we can read something relevant between the lines, because the Coman told William that Batu had asked him "multa about them and "ipse dixerat ei conditiones Ordinis nostri«. Immediately after that, William remembers having seen Batu riding with the heads of all the families: they were no more than "five hundred men «. This is relevant political information for Louis IX, who must be informed about the number of the Mongols. After all, the Epilogus of the Itinerarium ends up with military considerations about the French army and political suggestions to the pope. ${ }^{75}$

A comparison between the episodes shows that Priscus chose to highlight a contrast and William a consolation: the same Hun-Greek man was proud of his life at the beginning, but at the end of the dialogue he burst into tears of homesickness; William and Bartholomeus had been starving to death when they were visited first by some Hungarians who fed them, then by the Coman who had spoken well of them to Batu. From a literary perspective, this is a peaceful break before William's dramatic departure to Möngke. ${ }^{76}$

\section{Polygamy and Women's Power}

Villages were controlled by Hun kings through careful marriage politics, which left nothing to chance. For example, during Priscus' visit at Attila's camp the latter moved away to marry a young girl, Eskam's daughter, who was just one wife out of the many he had. Then the king left that village. ${ }^{77}$ A young newlywed, named Ildico, was the only witness of Attila's death in 453 and for this reason was also suspected of murder. ${ }^{78}$

During the absence of their husbands, Hun women had long been in charge of controlling the territory: Priscus himself met one of the widows of Bleda, the brother whom Attila had killed a few years earlier, and noticed that she was the boss of that village down to the slightest detail. ${ }^{79}$

75 William, Itinerarium, Epilogus 4-5, ed. Chiesa, 320; trans. Rockhill, 282: "It seems to me inexpedient to send another friar to the Tartars, as I went, or as the preaching friars go; but if the Lord Pope, who is the head of all Christians, wishes to send with proper state a bishop, and reply to the foolishness they have already written three times to the Franks [,,,] he would be able to tell them whatever he pleased, and also make them reply in writing. They listen to whatever an ambassador has to say, and always ask if he has more to say; but he must have a good interpreter - nay, several interpreters - abundant travelling fund, etc." See the conclusions below.

76 William, Itinerarium XX 6, ed. Chiesa, 100-101; trans. Rockhill, 128: «(...) there came a rich Moal to us, whose father was a chief of a thousand, which is a high rank among them, and he said: "I am to take you to Mangu chan. The journey is a four months one, and it is so cold on it that stones and trees are split by the cold. Think it over whether you can bear it.« I answered him : "I trust that, by the grace of God, we may be able to bear what other men can bear." Then he said : »If you cannot bear it, I shall abandon you on the road. «I replied : "That is not right; we are not going of ourselves, but are sent by your lord, so, being entrusted to your care, you should not abandon us." Then he said : "All will be well.«»

77 Priscus, Excerpta, 8, 63, ed. Carolla, 28; trans. Given, 56.

78 Priscus, Excerpta, 23, ed. Carolla, 62 (the fragment is transmitted by Jordanes, Getica); trans. Given, 112: »At the time of his death, as Priscus the historian reports, Attila married an exceedingly beautiful girl, Ildico by name, the last of his innumerable wives, as was the custom of that nation. (...) Late the following day, royal courtiers, suspecting something sorrowful, broke through the great doors and discovered Attila's unwounded corpse (...) and they found the girl crying under a cover, her face turned down." See also John Malalas, Chronicle, 14, 10, ed. Thurn, 279; trans. Jeffreys et al., 195: "This girl was suspected of having murdered him."

79 Priscus, Excerpta, 8, 66-73, ed. Carolla, 29-30 for the episode of the storm, the labyrinth and the powerful widow. About Bleda, probably killed in 445, see Theophanes, Chronography, AM 5942, ed. de Boor, 102; trans. Mango and Scott, 159: "Attila (...) after getting rid of his elder brother Bdellas, became sole ruler of the empire of the Scythians whom they call Huns.« 
William was also struck by the numerous and diverse wives of the Mongol khans, as well as by their ability to live together. For example, the most powerful wife of Möngke had been a Christian woman; when she died her daughter, also a Christian, inherited that power. Then Möngke married a young girl, which entered the number of his wives at a lower rank; yet, as she was rreplacing the Christian one, she used to live with the latter's daughter and got along very well with her. ${ }^{80}$

\section{The King's Power}

Attila's power, as Priscus puts it, was so overwhelming for both partes imperii that he received official honours and tributes, payed in gold only, and we are told that he sent ambassadors to Constantinople again and again, only because he wanted them to be covered in gold. ${ }^{81}$ One of these men was Edekon, who plotted the conspiracy with the Byzantine officials and then told everything to Attila.

William, for his part, describes repeatedly the immense land strictly controlled by the Mongols via tributes and slavery. ${ }^{82}$

\section{Food, Drinks \& Banquets}

Both Priscus and William found millet instead of wheat on their way. ${ }^{83}$ Priscus reported that Huns called their drinks >medos` and 'kamon ‘, ${ }^{84}$ whereas William records terms like >comos`, scaracomos` for horse milk and, occasionally, also sbal f for a drink made with honey and sterracinar for the beer of rice. ${ }^{85}$

A modern reader is astonished to learn that William could be satiated by drinks like broth or comos, ${ }^{86}$ a fact which cannot be fully explained even by the Franciscan dietary restrictions: he also thought it normal for the Mongols and complained whenever they were stingy in comos. ${ }^{87}$

The Byzantine ambassador and his entourage were invited to a banquet on three occasions, while at Attila's court: two were invitations by the king, the other by Kreka the queen. ${ }^{88}$

80 William, Itinerarium II 4, ed. Chiesa, 22; 8, ibid., 24; X 3, ibid., 52; XXIX 19, ibid., 174-176.

81 For this reason some scholars assume that Attila's power was actually fragile and that he needed to motivate his generals or rather to control their ambition. See e.g. Thompson and Heather, Huns, esp. 187-189.

82 Especially William, Itinerarium IV 5, ed. Chiesa, 32 (Baatu); XII 4, ibid., 60 (tax on salt); XXXVIII 6-7, ibid., 308310 (powerful Armenians stripped off by the Mongols) et passim.

83 Priscus, Excerpta, 8, 65, ed. Carolla 28; trans. Given, 57; William, Itinerarium XIII 12, ed. Chiesa, 68.

84 Priscus, Excerpta, 8, 65, ed. Carolla, 28; see also Gelzer, Médos bei Priskos.

85 William, Itinerarium III 1, ed. Chiesa, 28; IV 1, ibid., 30; IV 6, ibid., 32 for the "grut « (comos boiled until solidification). For the importance of comos in Mongol food see XII 2-3, ibid., 58; XVIII 2, ibid., 88; XXX 1, ibid., 210.

86 William, Itinerarium XXII 1, ed. Chiesa, 106-108.

87 William, Itinerarium XXXVII 23, ed. Chiesa, 302.

88 Priscus, Excerpta, 8, 151-173 (Attila); 178-179 (Kreka); 180-187 (Attila), ed. Carolla, 43-49; trans. Given, 72-78. 


\section{Prophecies}

During the first banquet, Priscus came to know Attila's predilection for his youngest son because of a prophecy which the king treasured: "I was amazed that he might be slighting his other children by paying attention to that son, but the barbarian sitting next to me, who understood Ausonian [i.e., Latin] and told me to repeat nothing of what he was going to tell me, said that prophets had predicted to Attila that his nation would fall but that it would rise again under this son ${ }^{89}{ }^{89}$ Elsewhere Priscus had reported Attila's trust in the "sword of Ares, an object holy and honored among royal Scythians because it was dedicated to the overseer of wars, which had disappeared long ago but was discovered with a bull's help. $^{90}$

However, the reverse was true, as Priscus did not fail to highlight: a passage of Jordanes taken from Priscus informed the readers that «a divinity stood above the Eastern emperor Marcian in his sleep. He had been suffering anxiety because of his fierce enemy. The dream showed him that the bow of Attila had been broken that very night, as if because the Huns relied so much upon that weapon. Priscus the historian says he received a true testimonial and so accepts this story. For Attila was considered so frightful to great empires that the gods revealed his death to rulers as a gift. «"1

It is easy to detect the literary pattern between the lines, however fragmentary: although proud of his fortune, Attila fell because the same god in which he had trusted turned his back and abandoned him. Moreover, even that pagan divinity payed homage to the Christian emperor Marcian (and not to the Western emperor, who in 453 was Valentinianus III). It was a story of hybris and punishment, perfect for demonstrating the Hun presumption and the excellence of Constantinople over Ravenna.

William wanted his king to be informed about a prophecy regarding the Mongols and appropriately put it at the end of his journey, recounting that he was told by an Armenian bishop in Nakičevan: "Alius propheta uocatur Acaton, qui in morte sua prophetauit de gente sagittaria uentura ab aquilone, dicens quod "Ipsi acquirent omnes terras orientis, et parcent regno orientis ut eis tradat regnum occidentis; sed fratres nostri (id est Franci uiri catholici) non credent eis. Et occupabunt terras ab aquilone usque in meridiem, et peruenient usque Constantinopolim et occupabunt portum Constantinopolitanum. Et unus ex eis, qui uocabitur uir sapiens, ingredietur ciuitatem, et uidens ecclesias et ritum Francorum faciet se baptizari, et dabit Francis consilium qualiter interficient dominum Tartarorum, et ibi confundentur. Hoc audientes qui erunt de medio terre (id est Ierusalem) insilient in Tartaros qui

89 Priscus, Excerpta, 8, 172-173, ed. Carolla, 47; trans. Given, 80.

90 Priscus, Excerpta, 8, 146, ed. Carolla, 42; trans. Given, 70. See also fr. 10 (from Jordanes), ed. Carolla, 53; trans. Given, 70-71.

91 Trans. Given, 112. Priscus, Excerpta, 23, ed. Carolla, 62. 
erunt in finibus eorum, et cum adiutorio nostre gentis (hoc est Hermenorum) persequentur eos, ita quod apud Taurinum in Perside ponet rex Francorum solium regale. Et tunc conuertentur omnes orientales et omnes increduli gentium ad fidem Christi, et erit tanta pax in mundo quod uiui dicent mortuis: /Ve uobis qui non uixistis usque ad tempora ista! « ${ }^{92}$

The prophecy was told by an Armenian monk who was also a bishop, and his entourage were twelve monks. Apparently, what William heard was the same as the Visio Norsei, ${ }^{93}$ with one crucial change: the "gens sagittaria" was there identified with the Mongols and not with the Seljukid Turks. ${ }^{94}$

Did William summarise and twist the oral text? An Armenian source might have done so, in order to persuade the French king, Louis IX, and have him attack the enemies of Armenia: not only the Mongols, but also the Muslims. This would make sense, especially because Armenians after the first Crusade re-interpreted the ancient prophecy identifying their help from Franks and no longer from the Byzantines. ${ }^{95}$ Furthermore, Pertusi suggests that Armenians re-adapted the prophecy from Late Antiquity throughout the Middle Ages until the fall of Constantinople; ${ }^{96}$ if the prophecy was readjusted to new situations every time, it is possible that a 5 th-century-old nucleus referred to Huns, a "gens sagittaria " who devastated the East "ab aquilone usque in meridiem «. We must remember that Attila came down to Constantinople in 447, when part of the walls collapsed because of an earthquake. ${ }^{97}$ And the enemy who came with hostile thoughts as an ambassador, only to convert to Christianity and suggest how to kill his own king, might even have links to the failed conspiracy plotted by the Byzantine court with Attila's envoy, Edekon. ${ }^{98}$ In that case, the latter could have been just

92 William, Itinerarium, XXXVIII 3, ed. Chiesa, 304; trans. Rockhill, 268-269: "The other prophet is called Acatron, who on his death-bed prophesied concerning the race of Archers to come from the north, saying that they would acquire possession of all the countries of the Orient, and that (God) would spare the Eastern kingdom so as to deliver unto them the kingdom of the West; but our brethren, like the Catholic Franks, would not believe in them, and they (i.e., the Archers) would occupy the earth from the north even unto the south, and would come to Constantinople, and would occupy the port of Constantinople; and one of them, who would be called a sage, would enter the city, and seeing the churches and the ceremonies of the Franks would be baptised, and he would tell the Franks how to kill the lord of the Tartars, and how to confound them. On learning this the Franks of the centre of the world, that is Jerusalem, would fall upon the Tartars in their borders, and with the help of our people, that is the Hermenians, would pursue them, so that the King of the Franks would place his royal throne in Tauris in Persia, and then all the Orientals and all the infidels would be converted to the faith of Christ, and there would be such peace on earth that the living would say to the dead: 'Woe is you, unfortunate ones, why lived ye not to these times?«.

93 About the Armenian Life of Nerses (LN), where the Visio is included, see the recent contributions: Pogossian, Armenians, Mongols and the end of times, 169-178 and 181-182 (esp. 169-170 n. 4; 182 n. 79); Pogossian, Last emperor or the last Armenian king?, 457-503. The Latin text of the Visio Norsei can be found in Pertusi, Visio Norsei, 130-135, who dates it to the first half of the 12th century; its relationship with the Armenian Life of St. Nerses (probably reworked slightly before the beginning of the 12th century, with some material older than the 5th century) is discussed ibid., 135-148 and with ps.-Epiphanius, Sermo de Antichristo, ibid., 148-149 (from the same period as the Visio Norsei). See also Pertusi, Conclusione, 151-155. That William is referring to the Visio Norsei is argued by most scholars, including Chiesa, Commento, 502-503.

94 Chiesa, Commento, 502; see also Scodellaro, Oracolo inedito, 26-27.

95 E.g., Matt'ēos Urhayec'i: see Pogossian, Last emperor or the last Armenian king?, 472-473.

96 Pertusi, Visio Norsei, 142-150; see also Scodellaro, Oracolo inedito, 26-27.

97 Thompson and Heather, Huns, 90-94.

98 About Edekon's role in plotting the conspiracy see Priscus, Excerpta, 7, 1-14, ed. Carolla, 13-15; trans. Given, 44-46. 
an inspiration for the production of a (now lost) idealised text in a myaphysite environment, favourable to the powerful eunuch Chrysaphius and his followers. It is only a hypothesis, of course; yet, if the prophecy had different "layers" throughout times, that could have been one of them.

\section{Which Constantinople?}

What is more interesting in the comparison between Priscus and William is that their journeys moved in completely divergent directions - Priscus towards Pannonia and beyond the Danube, William to Inner Asia and the Caspian Sea - but they brought vivid memories of the city of cities from their start. Most probably Priscus had previously lived in the capital, even though we do not know anything for sure. William, on the contrary, crossed Constantinople at the beginning of the journey and is said to have spoken publicly in St. Sophia on Palm Sunday. We may ask ourselves which image and aspect of Constantinople he brought to mind in the desolated land of the Mongols. His Constantinople was that of the Latin Empire, not the Byzantine one which would have prevailed a few years later; ${ }^{99}$ yet the polyphony of peoples and cultures was still there, especially in William's perception. ${ }^{100}$ This is why he remembered having read the prophecy in Constantinople specifically, thanks to some Armenians who had shown it to him there and he added: "sed non curaueram; sed quando locutus fui cum dicto episcopo, tunc memor magis curaui.$^{101}$ After all, the monk he lived with at Möngke's court was Armenian; ${ }^{102}$ a region where Armenians were living under the yoke of the Mongols inspired in him the sensation that Christians could overcome not only the Mongols, but also the Turks. ${ }^{103}$ Finally, whenever he claimed that Christian peasants could conquer the whole world, provided that they were willing to learn Mongol speed and to eat the same food, he is applying the Armenian prophecy to a real political context. ${ }^{104}$

We may infer that Armenians, expert in contact with every >Other«, were his facilitators in detecting the key to the >Otherness`. Or perhaps Armenian Otherness was the key to his (image of) Constantinople.

99 In 1261, after the Byzantine conquest of the City of cities, the emperor Michael VIII Palaiologos re-entered the Golden Gate as is attested by Georgios Acropolites I, ed. Heisenberg, 186-188.

100 For different perceptions of Constantinople through the centuries see Ronchey and Braccini, Romanzo di Costantinopoli; Braccini, Bisanzio prima di Bisanzio.

101 William, Itinerarium, XXXVIII 3, ed. Chiesa, 306; trans. Rockhill "I had read this prophecy in Constantinople, brought there by the Hermenians who live there, but had paid no particular attention to it; when I had had this conversation, however, with the bishop, it came back vividly to my memory".

102 Sergius the monk is a prominent character in William's narration, see e.g. ed. Chiesa, 149-151; 161-163; 171-175; 179 ; 185-195; 203-209; 225-231; 237-239; 283.

103 William, Itinerarium, XXXVIII 7, ed. Chiesa, 308-310.

104 See above nn. 92-95. 


\section{The Key to the >Otherness}

I offer here a reading of some relevant passages in both accounts: (a) Attila's messages to the emperors both in the East and in the West; ${ }^{105}$ (b) the long letter of Möngke to Louis IX. ${ }^{106}$ In my opinion, they summarise what the authors retained about >Otherness،.

The contents of the first and the last message by Attila look symmetrical: he asks that his requests be complied with, first regarding the restitution of $\phi u \gamma a ́ \delta \varepsilon \varsigma, ~ » d e s e r t e r s$ « who were, in fact, refugees, and afterwards about his asserted betrothal with Justa Grata Honoria Augusta, the sister of the emperor Valentinianus III. In both cases he threatens the Roman Empire that should his order not be satisfied, he will go to war; but the consequences in the two cases are the exact opposite of one another: while Theodosius II strives to obey Attila in 447, Marcian and Valentinianus dismiss his impossible demands in 450.

Most interesting is the third message, the one that Attila entrusts - orally, it seems - to the Byzantine ambassador Maximinus in 449. Here Theodosius II is openly challenged to show that he is an emperor and not a puppet: „Either, he [i.e., Attila] said, the audacious man would have paid the price, or the emperor's power was such that he did not even rule his own servants, against whom, if he would like, he was ready to provide an alliance. ${ }^{107}$ Here the >Other, however insolent, becomes what the author would have hoped to find in his emperor: bold, frank and able to make Theodosius accept his responsibilities. Praising Attila means belittling an emperor in name only.

The context of Khan Möngke's letter to Louis IX is different: the head of a vast empire speaks in the name of the one eternal god, on whom he relies for his earthly power. Furthermore, Möngke's words are interpreted through the wisdom of Psalms: he writes that his enemies "erunt habentes oculos non uidentes; et cum uoluerint aliquid tenere, erunt sine manibus; et cum uoluerint ambulare, erunt sine pedibus «. ${ }^{108}$ This is the way that William chooses to present the letter, no doubt because Psalm 114-115, 5-7 was what Möngke's words reminded him of.

Thus, the Khan's claim to be representative of the eternal god and his equation renemies = idolaters pave the way to William's recognition that the truth, in fact, is quite the opposite.

\section{The >Other, the Opposite}

So far we have detected many clues that reveal an identical perception, namely that travelling to the >Other entails an impact with the sopposites: what is contrary to their usual habits, traditions, ideas and practice becomes everyday life and experience for Priscus and William. Yet what both travellers retain is that their own side and situation should be the opposite of what it actually is. In other words, the perception of the >Otherness < becomes the perception of one's part to be sother than it should be: for instance, several times Priscus points out the

105 Priscus, Excerpta, 3, 1, ed. Carolla, 8 (Attila's letter to Theodosius II in 447); 8, 45-47, ibid., 25 (message for Theodosius II in 449); exc. 12.1, 1, ibid., 54 (official, oral answer to Theodosius in 449); exc. 15, ibid., 56 (envoys to Valentinianus III and Marcian in 450); trans. Given, 35, 54, 82 and 98.

106 William, Itinerarium, XXXVI 6-12, ed. Chiesa, 274-278; trans. Rockhill, 248-251.

107 Priscus, Excerpta, 12.1, 1, ed. Carolla, 54; trans. Given, 82.

108 Trans. Rockhill, 249: »they have eyes and see not; and when they shall want to hold anything they shall be without hands, and when they shall want to walk they shall be without feet«. 
failure of the emperor and his entourage, while William suggests learning from the Mongols their ability in speed and restraints with food, in order to conquer the whole world. ${ }^{109}$ Yet it is impossible to reduce their learning to a look-at-the-bright-side inspiration: indeed, Priscus' world appears turned upside down until the death of Theodosius II (450) and that of Attila (453); ${ }^{110}$ on the other hand, William feels acutely his own failure as a preacher among the Mongols. Here he takes one step further, as regards perception of the rotherness: he perceives himself to be sother (and probably the opposite) than his model. Saint Francis, the founder of his Order, was able to preach to the Sultan in Damietta and obtained permission for his brothers to visit the Holy Land. ${ }^{111}$ Perhaps this is why William, although a Franciscan friar, releases his work with the closing words about resources and money: »sed oporteret quod haberet bonum interpretem, immo plures interpretes, et copiosas impensas. «" ${ }^{112}$ Probably the opposite of what Francis of Assisi would have thought in the same situation.

Both Priscus and William bear witness to the last period of a political and cultural situation, to which they did not belong, yet to which they were linked: for Priscus it was the Roman Western Empire; for William, the Latin Empire in Constantinople. Both were periods of change and continuity which stimulated meditation on and self-awareness of imperial and Christian identities; in both cases the narrators struggled to resist the tides of change and pinpointed a tradition as a relief from the threat of the >Other the Eastern Roman Empire, the French Kingdom was suggested by William. No matter how mysteriously, both of them looked confident that their traditions would have survived the test as they had already done in the recent past - and they both contributed to a universal narrative of humanity, namely, that of Byzantium and the West.

\section{Biographical statement}

Pia Carolla is a tenure-track assistant professor in Byzantine Civilisation at the University of Genoa, Italy. She published a critical edition of Priscus of Panion in 2008 (Bibliotheca Teubneriana, W. de Gruyter); her research deals with Byzantine manuscripts, Medieval Greek textual traditions and their reception in the West up to the beginning of the 17th century.

109 William, Itinerarium, Epilogus 4, ed. Chiesa, 320; trans. Rockhill, 282 »I state it with confidence, that if your peasants - I speak not of the princes and noblemen - would but travel like the Tartar princes, and be content with like provisions, they would conquer the whole world".

110 See the recovery after the accession of the emperor Marcian to the throne: Priscus, Excerpta, 15, 1-2, ed. Carolla, 56; trans. Given, 98; and Marcian's dream about Attila's broken bow in the same night when the Hun king had died by haemorrhage: Priscus, Excerpta, 23, ed. Carolla, 62; trans. Given, 112.

111 For the different readings and interpretations of the sources, see Ibrahim, Francis preaching to the sultan.

112 William, Itinerarium, Epilogus 5, ed. Chiesa, 320; trans. Rockhill, 282 »but he [i.e., an ambassador to the Mongols] must have a good interpreter -nay, several interpreters - abundant travelling funds, etc. « See above, n. 75. 


\section{References}

Abbreviations

BBT = Golubovich, Girolamo, Biblioteca bio-bibliografica della Terra Santa e dell'Oriente francescano, serie I-III (Quaracchi, Firenze, 1906-1928).

$\mathrm{BT}=$ Bibliotheca Scriptorum Graecorum et Latinorum Teubneriana (Berlin).

CFHB = Corpus Fontium Historiae Byzantinae (Berolini - Novi Eboraci).

PLRE = Arnold Hugh Martin Jones, John Robert Martindale, John Morris, Edward Arthur Thompson, Alan D.E. Cameron and Philip Grierson (eds.), The Prosopography of the Late Roman Empire, 1-3 (Cambridge, 1971-1992, reprinted 2006).

Auzépy, Marie-France, Guillaume de Rubrouck chez les Mongols, in: Jacques Berlioz (éd.), Moines et religieux au Moyen Âge (Paris, 1994) 305-317.

Baldwin, Barry, Priskos, in: Alexander P.Kazhdan, Alice-Mary Talbot, Anthony Cutler, Timothy E. Gregory and Nancy P. Ševčenko (eds.), The Oxford Dictionary of Byzantium, 3 (New York, 1991) 1721.

Berardi, Francesco, La retorica degli esercizi preparatori: glossario ragionato dei Progymnásmata, Spudasmata 172 (Hildesheim, 2017).

Bonaventura, Legenda Maior $=$ Bonaventura de Bagnoregio, Legenda Major Sancti Francisci, in: Bonaventura de Bagnoregio, Opera omnia, 8 (Quaracchi, Firenze, 1898) 2-75. Accessed on 20 January 2019: www.documentacatholicaomnia.eu/o3d/1221-1274,_Bonaventura, Legenda_Major_Sancti_Francisci,_LT.pdf.

Bornmann, Fritz, Osservazioni sul testo dei frammenti di Prisco, Maia 26 (1974) 111-116.

Braccini, Tommaso, Bisanzio prima di Bisanzio. Miti e fondazioni della nuova Roma, Piccoli saggi 64 (Roma, 2019).

Chiesa, Paolo, Commento, in: William, Itinerarium, 323-515.

Chiesa, Paolo, Introduzione, in: William, Itinerarium, IX-LVI.

Chrysaphius, qui et Ztummas, PLRE 3, 295-297.

Dzino, Danijel and Ken Parry (eds.), Byzantium, its Neighbours and its Cultures, Byzantina Australiensia 20 (Brisbane, 2014).

Ernoul, Chronicle = Chronique d'Ernoul et de Bernard le Trésorier, in: Girolamo Golubovich (ed.), Biblioteca bio-bibliografica della Terra Santa e dell'Oriente francescano, serie I (Quaracchi, Firenze, 1906) 10-13; Italian translation: Francesco nei cronisti della quinta crociata. A) Cronaca di Ernoul, in: Caroli, Ernesto, Carlo Paolazzi, Felice Accrocca, Alfonso Marini et al. (eds.), Fonti Francescane. Nuova edizione (Padova, 2004).

Eunapius of Sardis, ed. Robert C. Blockley, The Fragmentary Classicising Historians of the Later Roman Empire. Eunapius, Olympiodorus, Priscus and Malchus, II. Text, Translation and Historiographical Notes, ARCA Classical and Medieval Texts, Papers and Monographs 10 (Liverpool, 1983) 1-127.

Gelzer, Heinrich, Médos bei Priskos, Byzantinische Zeitschrift, 24/2 (1923-1924) 313-314.

Georgios Acropolites = Georgii Acropolitae Opera, ed. August Heisenberg, BT (Leipzig, 1902).

Given, John, Introduction, in: John Given, The Fragmentary History of Priscus. Attila, The Huns and the Romans $A D$ 430-476, Christian Roman Empire Series 11 (Merchantville, NJ, 2014) xi-xliv. 
Gottschalk, Hans L., »al-Kāmil«, in: Peri J. Bearman, Thierry Bianquis, Clifford Edmund Bosworth, Emeri Johannes van Donzel, Wolfhart P. Heinrichs (eds.), Encyclopaedia of Islam, Second Edition (Leiden, 2012-). Accessed on 23 June 2019: dx.doi.org/10.1163/15733912_islam_COM_0432.

Greatrex, Geoffrey, Government and mechanism of control, East and West, in: Michael Maas (ed.), The Cambridge Companion to the Age of Attila, Cambridge Companions to the Ancient World (Cambridge, 2014) 26-43.

Gruen, Erich S., Rethinking the Other in Antiquity, Martin Classical Lectures (Princeton, 2011).

Howard-Johnston, James, Byzantium and its neighbours, in: Elizabeth Jeffreys, John Haldon and Robin Cormack (eds.), The Oxford Handbook of Byzantine Studies (Oxford, 2008) 939956.

Hoffmann, Lars Martin, Priscus of Panium, in: Graeme Dunphy and Cristian Bratu (eds.), Encyclopedia of the Medieval Chronicle (revised edition), (Leyden, 2016). Consulted online on 10 February 2019: dx.doi.org/10.1163/2213-2139_emc_SIM_02100.

Ibrahim, Mahmood, Francis preaching to the sultan: Art and literature in the hagiography of the saint, in: Cynthia Ho, Beth A. Mulvaney and John K. Downey (eds.), Finding Saint Francis in Literature and Art. The New Middle Ages (New York, 2009) 47-61.

John Malalas, Chronicle = Ioannis Malalae Chronographia, ed. Ioannes Thurn, CFHB Series Berolinensis 35 (Berlin, 2000); English translation: Elizabeth Jeffreys, Michael Jeffreys and Roger Scott, The Chronicle of John Malalas, Byzantina Australiensia 4 (Leiden, 1986, reprinted 2017).

John of Plano Carpini, Historia Mongalorum = Giovanni di Pian del Carpine, Storia dei Mongoli, ed. Paolo Daffinà, Claudio Leonardi, Maria Cristiana Lungarotti, Enrico Menestò and Luciano Petech (Spoleto, 1989, reprinted 2017).

Jordanes, Getica = Iordanis de origine actibusque Getarum, ed. Francesco Giunta and Antonino Grillone, Fonti per la storia d'Italia 117 (Roma, 1991).

Kaldellis, Anthony, Hellenism in Byzantium. The Transformation of Greek Identity and the Reception of the Classical Tradition, Greek Culture in the Roman World (Cambridge, 2007).

Kelly, Christopher, Neither conquest nor settlement: Attila's empire and its impact, in: Michael Maas (ed.), The Cambridge Companion to the Age of Attila, Cambridge Companions to the Ancient World (Cambridge, 2014) 193-208.

Laiou, Angeliki E., Byzantium and the Other. Relations and Exchanges, edited by Cécile Morrisson (Burlington, VT, 2012; reprinted London, 2018).

Lenski, Noel, Captivity among the barbarians and its impact on the fate of the Roman Empire, in: Michael Maas (ed.), The Cambridge Companion to the Age of Attila, Cambridge Companions to the Ancient World (Cambridge, 2014) 230-246.

Maas, Michael, Reversals of fortune: An overview of the age of Attila, in: Michael Maas (ed.), The Cambridge Companion to the Age of Attila, Cambridge Companions to the Ancient World (Cambridge, 2014) 3-25.

Magdalino, Paul, Constantinople and the outside world, in: Dion C. Smythe (ed.), Strangers to Themselves: The Byzantine Outsider, Papers from the Thirty-Second Spring Symposium of Byzantine Studies, University of Sussex, Brighton, March 1998. Publications of the Society for the Promotion of Byzantine Studies 8 (London, 2000; reprinted ebook 2016) 149-162.

Manfredi, Valerio Massimo, Il faraone delle sabbie (Milano, 1998, reprinted 2010). 
McCormick, Michael, Eternal Victory: Triumphal Rulership in Late Antiquity, Byzantium and the Early Medieval West (Cambridge, 19902); Id., Vittoria eterna. Sovranità trionfale nella tarda antichità, a Bisanzio e nell'Occidente altomedievale, Cultura e Storia (Milano, 1993).

Mitsiou, Ekaterini, The Byzantines and the "others«. Between transculturality and discrimination, in: Christian Gastgeber and Falko Daim (eds.), Byzantium as Bridge between West and East, Proceedings of the International Conference, Vienna, 3rd-5th May 2012, Veröffentlichungen zur Byzanzforschung 36 (Vienna, 2015) 65-74.

Morini, Enrico (ed.), Pertusi, Agostino, Fine di Bisanzio e fine del mondo. Significato e ruolo storico delle profezie sulla caduta di Costantinopoli in Oriente e in Occidente, Nuovi studi storici 3 (posthumous edition, Istituto storico italiano per il Medio evo), (Roma, 1988).

Olympiodorus of Thebes, ed. Robert C. Blockley, The Fragmentary Classicising Historians of the Later Roman Empire. Eunapius, Olympiodorus, Priscus and Malchus, II. Text, Translation and Historiographical Notes, ARCA Classical and Medieval Texts, Papers and Monographs 10 (Liverpool, 1983) 151-209.

Pertusi, Agostino, Conclusione (Seconda stesura provvisoria), in: Enrico Morini (ed.), Pertusi, Agostino, Fine di Bisanzio e fine del mondo. Significato e ruolo storico delle profezie sulla caduta di Costantinopoli in Oriente e in Occidente, edizione postuma, Istituto storico italiano per il Medio evo. Nuovi studi storici 3 (Roma, 1988) 151-155.

Pertusi, Agostino (ed.), La »Visio Norsei«, profezia di S. Nersete il Grande e il »Sermo de Antichristo« dello pseudo-Epifanio, in: Enrico Morini (ed.), Pertusi, Agostino, Fine di Bisanzio e fine del mondo. Significato e ruolo storico delle profezie sulla caduta di Costantinopoli in Oriente e in Occidente, edizione postuma, Istituto storico italiano per il Medio evo. Nuovi studi storici 3 (Roma, 1988) 128-150.

Pittaluga, Stefano, Lo sguardo dell'altro, Itineraria 10 (2011) 23-32.

Pohl, Walter, Migrations, ethnic groups, and state building, in: Michael Maas (ed.), The Cambridge Companion to the Age of Attila, Cambridge Companions to the Ancient World (Cambridge, 2014) 247-263.

Pohl, Walter, Identità etniche e cristianesimi, in: Luca Arcari (ed.), Identità etniche, identità collettive, identità religiose. Problemi aperti in prospettiva diacronica, special issue Reti Medievali Rivista 16.1, 2015, 59-72, DOI: dx.doi.org/10.6092/1593-2214/460.

Pohl, Walter, Conclusion: The transformation of frontiers, in: Walter Pohl, Ian Wood and Helmut Reimitz (eds.), The Transformation of Frontiers From Late Antiquity to the Carolingians, The Transformation of the Roman World (Leiden, 2001) 247-260.

Pogossian, Zaroui, Armenians, Mongols and the end of times: An overview of 13th century sources, in: Tubach, Jürgen, Sophia G. Vashalomidze and Manfred Zimmer (eds.), Caucasus during the Mongol Period - Der Kaukasus in der Mongolenzeit (Wiesbaden, 2012), 169-198.

Pogossian, Zaroui, The last emperor or the last Armenian king? Themes in Armenian texts from the Cilician period, in: Kevork B. Bardakijan and Sergio La Porta (eds.), The Armenian Apocalyptic Tradition. A Comparative Perspective. Essays Presented in Honor of Professor Robert W. Thomson on the Occasion of His Eightieth Birthday (Leiden, 2014) 457-503. 
Priscus, Excerpta = Priscus Panita, Excerpta et Fragmenta, ed. Pia Carolla, BT (Berlin, 2008); English translation: John Given, The Fragmentary History of Priscus. Attila, The Huns and the Romans AD 430-476, Christian Roman Empire Series 11 (Merchantville, NJ, 2014); Greek edition with different numeration of the fragments: Robert C. Blockley, The Fragmentary Classicising Historians of the Later Roman Empire. Eunapius, Olympiodorus, Priscus and Malchus, II. Text, Translation and Historiographical Notes, ARCA Classical and Medieval Texts, Papers and Monographs 10 (Liverpool, 1983) 222-376; Greek edition and Italian translation: Fritz Bornmann, Prisci Panitae Fragmenta (Firenze, 1979).

Pubblici, Lorenzo, Antagonism and coexistence. Local population and western merchants on Venetian Azov Sea in the 14th century, in: Claudia Pieralli, Claire Delaunay and Eugène Priadko (eds.), Russia, Oriente slavo e Occidente europeo. Fratture e integrazioni nella storia e nella civiltà letteraria, Biblioteca di Studi slavistici 36 (Firenze, 2017) 25-47.

Ronchey, Silvia and Tommaso Braccini, Il Romanzo di Costantinopoli. Guida letteraria alla Roma d'Oriente (Turin, 2010; reprinted 2016).

Scodellaro, Alberto, Un oracolo inedito sulla caduta di Costantinopoli, Tesi di Laurea in Scienze dell'Antichità, Università Ca' Foscari Venezia (Venezia, 2014). Accessed on 18 February 2019: hdl.handle.net/10579/4448.

Theophanes, Chronography = Theophanis Chronographia, ed. Carl de Boor, Bibliotheca Teubneriana (Lipsiae 1883); English translation: Cyril Mango and Roger Scott with the assistance of Geoffrey Greatrex, The Chronicle of Theophanes Confessor. Byzantine and Near Eastern History AD 284-813 (Oxford, 1997).

Thompson, Edward Arthur, The camp of Attila, Journal of Hellenic Studies 65 (1945) 112-115.

Thompson, Edward Arthur, Notes on Priscus Panites, The Classical Quarterly 41/1-2 (1947) 61-65.

Thompson, Edward Arthur and Peter Heather, The Huns, The Peoples of Europe (Oxford 1996, reprinted Malden, Ma, 2006).

Treadgold, Warren, The Early Byzantine Historians (Basingstoke, 2007).

Vermeulen, Jan, William van Rubroec in Mongolie, Leidschrift 12 (1997) 103-130.

Vindobona. Vienna International News, Lasting Rivals - Byzantium \& the West, 4 June 2018. Retrieved on 10 February 2019: www.vindobona.org/article/lasting-rivals-byzantiumand-the-west.

William, Itinerarium = William of Rubruk, Itinerarium, ed. Paolo Chiesa, Guglielmo di Rubruk. Viaggio in Mongolia (Itinerarium), Scrittori greci e latini (Milano, 2011); English translation: Peter Jackson and David Morgan, The Mission of Friar William of Rubruck. His Journey to the Court of the Great Khan Möngke 1253-1255, Hakluyt Society, second series, [e-book] (London, 2011; re-issued 2017). Retrieved on 10 February 2019: books.google.it/books?id=JAgkDwAAQBAJ\&printsec=frontcover\&hl=it\#v=onepage\&q\&f=false. Former English translation: William Woodville Rockhill, The Journey of William of Rubruck to the Eastern Parts of the World, 1253-55, Hakluyt Society (London, 1900; reprinted e-book 2017). 